Collecting and analysing creole data

\title{
Sippola, Eeva
}

de Gruyter

2018

Sippola , E 2018 , Collecting and analysing creole data . in W Ayres-Bennett \& J Carruthers (eds) , Manual of Romance Sociolinguistics . Manuals of Romance Linguistics , no. 18 , de Gruyter , Berlin , pp. 91-113 . https://doi.org/10.1515/9783110365955-004

http://hdl.handle.net/10138/324062

https://doi.org/10.1515/9783110365955-004

unspecified

publishedVersion

Downloaded from Helda, University of Helsinki institutional repository.

This is an electronic reprint of the original article.

This reprint may differ from the original in pagination and typographic detail.

Please cite the original version. 


\title{
Eeva Sippola
}

\section{Collecting and analysing creole data}

\begin{abstract}
This chapter discusses specific methodological concerns when working with creoles. We provide a survey of data collection techniques employed in the analysis of social variation and language use in Romance creole settings. A presentation of Romance creoles and previous sociolinguistic and dialectological research on them is followed by a discussion of central concepts in the study of creoles: diglossia, creole continuum, prestige asymmetry, and language endangerment. Best practices in the collection and analysis of creole data focus on ethical aspects and contextualization of research with creole communities, and access to data through participant observation, interviews, and surveys. The chapter ends with a case study of Chabacano perceptual dialectology that combines several sociolinguistic methods in the collection of data on variation and speaker perceptions in a multilingual setting.
\end{abstract}

Keywords: creoles, prestige asymmetry, data collection, methods, ethics

\section{Introduction}

This chapter will discuss the specific methodological concerns in the sociolinguistic study of Romance creoles (see also 715 Medium and creole). Creoles are languages that arose in situations of intense contact, where people of diverse ethno-cultural and linguistic backgrounds came together, often under conditions of slavery or indentured labour, and formed distinct communities and languages. Social history is central in the definition of creoles (DeGraff 2005; Mufwene 2008), as structural definitions of creole languages are still under debate (cf. McWhorter 2005; Bakker et al. 2011).

Romance creoles are contact varieties with a Romance lexifier language: French, Portuguese, or Spanish. There are no known creoles with other Romance lexifiers. ${ }^{1}$ Romance creoles were born in a contact situation where the lexifier language came in contact with other languages. These languages are called substrates, if they were present during the initial contact period but lost after the creolization process, or adstrates, when they continued to be spoken alongside the creole. Romance creoles are spoken in various settings around the world, ranging from Colombia and the Caribbean to Southeast Asia and the Pacific regions. These regions correspond to areas near the equator, where the Europeans established trade routes and colonies from the fifteenth century onwards. In connection to the colonial expansion, many

1 Restructured Italian in Eritrea has sometimes been mentioned (Holm 1988-1989, 609). 
creoles arose in the context of slavery, indentured labour, and plantation economies, as for example the Caribbean and Indian Ocean creoles. Others had their origins in religious missions, such as Tayo, or in multilingual urban or fort settings, as for example many Indo-Portuguese creoles.

Socio-historical issues are woven into the birth and the development of creoles, and studying the sociolinguistics of Romance creoles can help to address questions about how these creoles have developed and changed over time, either internally or in response to lexifier or adstrate influence. These developments have been shaped by the socio-historical contexts of the creoles as well as their speakers' identities and ideologies. Beyond creole studies, the study of creole languages can contribute to research questions that are important for the development of other Romance languages, as they can serve as extreme testing grounds for models of sociolinguistic variation and change.

In principle, creole languages should be studied using the same methods as any other natural languages. However, creoles have a social history that is tightly connected to colonialism, or other situations with unequal power relations, and they have often suffered a long history of stigmatization (Velupillai 2014, 45), which requires special attention to methodological approaches (on a related topic see also $\pi 5$ Romance dialectology). Language contact and asymmetrical power relations in many creole communities are central to these methodological concerns. In this chapter, we will address methodological issues through a number of examples from a variety of language contact situations. Our focus will be primarily on methods of data collection during fieldwork, but we will also give an overview of other sociolinguistic studies of Romance creoles in section two.

Romance creole languages vary greatly in vitality and social status, ranging from extinct languages (e.g. Batavia Creole) to languages of wider communication between different ethnic groups (e.g. Zamboanga Chabacano) and official languages with millions of speakers (e.g. Haitian Creole). Due to this diversity, it is challenging to give a comprehensive overview of the methods suitable for each sociolinguistic setting. However, in this chapter, we offer examples from a general perspective, encompassing a range of creoles with different lexifiers, geographical regions, and sociolinguistic situations.

The chapter is organized as follows: section two gives a short introduction to the Romance creoles and their study from different sociolinguistic perspectives. Section three presents some central concepts in the study of creole languages that have an effect on sociolinguistic methodology. Section four presents a number of specific methodological concerns in the collection and analysis of spoken creole data. The final section provides an example of a study of perceptual dialectology in the Chabacano-speaking communities in the Philippines, combining a variety of approaches. 


\section{Romance creoles and sociolinguistics}

Romance creole languages are spoken around the globe, mostly in tropical regions ranging from the South American mainland to the Pacific Islands. Table 1 presents the varieties generally classified as creoles with a lexifier from the Romance language family. $^{2}$

Table 1: Romance creoles in the Atlas of Pidgin and Creole Structures (Michaelis et al. 2013)

\begin{tabular}{|c|c|c|}
\hline Language & Region & Number of speakers (ca.) \\
\hline \multicolumn{3}{|l|}{ French-lexifier creoles: } \\
\hline $\begin{array}{l}\text { Haitian Creole (Haiti and } \\
\text { diaspora) }\end{array}$ & Caribbean & $11,000,000$ \\
\hline Guadeloupean Creole & Caribbean & 600,000 \\
\hline Martinican Creole & Caribbean & 600,000 \\
\hline Guyanais & Caribbean & 64,000 \\
\hline Louisiana Creole & North America & less than 10,000 \\
\hline Reunion Creole & Indian Ocean & 800,000 \\
\hline Mauritian Creole & Indian Ocean & $1,300,000+$ \\
\hline Seychelles Creole & Indian Ocean & 100,000 \\
\hline Tayo & New Caledonia & 3,000 \\
\hline
\end{tabular}

Portuguese-lexifier creoles:

\begin{tabular}{lll}
\hline $\begin{array}{l}\text { Cape Verdean Creole (Santiago, } \\
\text { Brava, São Vicente) }\end{array}$ & 555,000 \\
\hline Guinea-Bissau Kriyol & Upper Guinea & 600,000 \\
\hline Casamancese Creole & Upper Guinea & $10,000-50,000$ \\
\hline Santome & Gulf of Guinea & $100,000(2001)$ \\
\hline Angolar & Gulf of Guinea & 5,000 \\
\hline Principense & Gulf of Guinea & less than 100 \\
\hline Fa d'Ambô & Gulf of Guinea & $4,500-5,000$ \\
\hline Diu Indo-Portuguese & South Asia & 180 \\
\hline
\end{tabular}

2 This chapter focuses on the methodological challenges of studying the sociolinguistics of creoles. For structural, historical, and current information on Romance creoles we refer the reader to the descriptions in Holm (1988-1989) and in Volume II of the Atlas of Pidgin and Creole Language Structures (Michaelis et al. 2013). 
Table 1: (continued)

\begin{tabular}{lll}
\hline Language & Region & Number of speakers (ca.) \\
\hline Korlai & South Asia & $800+$ \\
\hline Sri Lanka Portuguese & South Asia & unknown \\
\hline Papiá Kristang & Southeast Asia & 800 \\
\hline
\end{tabular}

\begin{tabular}{lll}
\hline Spanish-lexifier creoles: & & \\
\hline Ternate Chabacano & Philippines & $\sim 3,000$ \\
\hline Cavite Chabacano & Philippines & 4,000 \\
\hline Zamboanga Chabacano & Philippines & 300,000 \\
\hline Papiamentu & & 300,000 \\
\hline Palenquero & Caribbean & $2,000-4,000$ \\
\hline
\end{tabular}

The Romance creoles include highly endangered varieties and vital languages with an official status. For example, the once-numerous Indo-Portuguese varieties are facing language death: the last speaker of the Indo-Portuguese creole of Cochin died in 2010. Very different situations are also common; for example, Mauritian Creole is vigorous with more than one million speakers, and Haitian Creole is comparable to other Romance languages with 11 million speakers in Haiti and in the diaspora.

Many Romance creole languages carry low prestige, as creoles typically exist in functional complementary distribution with the lexifier or other standard languages. Of the languages listed in Table 1, only Haitian Creole, Seychelles Creole, and Papiamentu have an official status. Others are officially designated as regional or local languages, such as Cape Verdean Creole and Zamboanga Chabacano. Moreover, most Romance creoles have no standard orthography and are not as extensively used in writing as their lexifiers or ad-/substrate languages (see also Mühleisen 2005). Relatedly, they are generally not accepted as languages of education or the media, although there are some exceptions: Papiamentu is used in some preschools and primary schools in the Netherlands Antilles, and Seychelles Creole is the medium of instruction in primary schools in the Seychelles (Migge/Léglise/Bartens 2010).

Language endangerment is a threat for some of the smaller Romance creoles (see also $\pi 4$ Fieldwork and building corpora for endangered varieties). This correlates with the fact that many of them are rather poorly documented. It is therefore crucial to

3 Papiamentu has significant input from Portuguese, but due to its current lexicon and proximity to Spanish-speaking Venezuela, it is classified here as a Spanish-lexifier creole. 
document the current state of these creoles, as this can offer greater insight into the linguistic diversity of contact situations and be useful for language planning and preservation purposes. The documentation includes not only descriptive studies but also sociolinguistic studies on the attitudes and ideologies that creole speakers have about their languages and others in the local, national, or global context. There are a number of studies assessing the sociolinguistic situation of Romance creole-speaking communities, especially in the Asian contexts, where language endangerment is a threat (see e.g. Cardoso 2009, 11-30 for Diu Indo-Portuguese; Lesho/Sippola 2013 for the Manila Bay varieties of Chabacano; Nordhoff 2013 for Sri Lanka Portuguese). In the Caribbean, the French creoles spoken in the Lesser Antilles are considered endangered in some locations, where speakers are shifting to another language, generally English or an English-lexifier creole (Ferreira 2009; Holbrook/Ferreira 2002). Similar situations are also seen elsewhere in small communities, although low speaker numbers do not necessarily mean inevitable language death. For example, the speakers of Fa d'Ambô form one of the smallest speech communities of Equatorial Guinea, but experts agree that due to its prestige, the vitality of the creole is not at immediate risk (Hagemeijer/Zamora 2016, 202).

Apart from issues related to endangerment and documentation, questions concerning historical sociolinguistics, language variation and change, language attitudes, and applied sociolinguistics have received attention in the sociolinguistic study of Romance creoles. These approaches highlight various themes in creole studies, covering processes of creole origins and formation, diachronic and synchronic variation, as well as language attitudes, ideologies, policies, and planning. Due to the challenge of limited materials they all require methodological precision and a contextualization of the social settings where creoles were and are spoken. We will consider each of these approaches in turn.

Historical sociolinguistics is at the core of creole studies, as it can help to answer questions about the formation and origins of these varieties. Most work describing the social composition of early Romance creole societies has been done from historical and archival sources (e.g. Baker/Corne 1982; Cardoso 2010; 2014; Chaudenson 1979; 2001; Clements 2014; Fernández/Sippola 2017; Ludwig/Telchid/Bruneau-Ludwig 2001; Singler 1995; Tomás 2009). The oral nature of many creole languages makes written data sources less prominent for current creole sociolinguistics. Old written texts are relatively sparse, although they are necessary for studying the diachrony and roots of sociolinguistic variation in these languages. When working with early sources, it is important to study and contextualize them carefully. Early written data cannot always be taken as evidence of simple diachronic progression (Cardoso 2014, 109) as they typically ignored certain registers or might not have been written by the speakers themselves but by outside observers. Today, through the rise of new online communication technology and mobile phones, creole languages have expanded to new written domains (e.g. Dupré 2013; Tobar Delgado 2014). The challenges associated with adapting written data to the needs of sociolinguists are shared across 
creole situations, and great methodological precision and transparency is necessary in the selection and treatment of data.

Sociolinguistic variation studies have not been very prevalent for Romance creoles (for exceptions, see e.g. Clements 1990; 2014; Lipski 1986; Morton 2005; Valdman/Villeneuve/Siegel 2015), especially when compared to similar studies on English-lexifier creoles. In many cases, variation is often analysed using traditional geographic and sociolinguistic models and focuses on the larger creoles, such as Haitian and Cape Verdean. The shortage of studies in this area is probably connected to the fact that many Romance creole studies have small sample sizes and data sets, and thus the full range of dialectal or social variation is not represented. For example, Cardoso (2014, 107-108) points out that the failure to recognize sociolinguistic variation in the Indo-Portuguese creole communities may actually be an outcome of our incomplete knowledge of these under-researched languages. It is likely that more instances of sociolinguistic variation could be identified if more scholars were to focus on these communities and their speech production.

Methods of traditional dialectology have been applied to the French creoles in the Caribbean and in the Indian Ocean. Linguistic atlases have been prepared for the islands of Haiti (Fattier 1998), Reunion and Rodrigues in the Indian Ocean (Carayol/ Chaudenson/Barat 1984-1995; Chaudenson/Carayol/Barat 1992), and for the Lesser Antilles (Le Dû/Brun-Trigaud 2011). Dialectal work for Cape Verdean Creole is also under way (Quint p.c.). These atlases have provided an extensive basis for further work on dialectal variation and processes related to it (e.g. Bollée/Nembach 2006).

In addition, identity, language ideologies, and applied linguistics have received attention in the study of Romance creoles (e.g. DeGraff 2005; Hebblethwaite 2009; Schieffelin/Doucet 1994, and Valdman 2005 for Haitian Creole; Lipski 2001; 2010, and Sippola 2010 for Chabacano; Graham 2001 for Portuguese creoles in Africa; Garrett 2005 for St Lucian Creole). Studying issues related to these topics often includes research on attitudes and folk perceptions (e.g. Carayol/Chaudenson 1978 for Reunion; Léglise 2005 for French Guiana; Lesho/Sippola 2014 for Chabacano; Mitchell 2010 for St Lucian Creole). From the perspective of language planning and policy, there are numerous studies (e.g. Bollée 1993 and Fleischmann 2008 for Seychelles; Kremnitz 1983 for Mauritius; Schnepel 2004 for Guadeloupe; Hazaël-Massieux 1993 and 2002 for the Lesser Antilles). In addition, the contributions in Ludwig (1989) and Bavoux/Prudent/Wharton (2008) deal with several applied perspectives regarding the French-lexifier creoles.

\section{Central concepts in the study of creole languages}

This section introduces some central concepts that are useful analytical tools in the study of creole languages and outlines how they affect data collection and analysis in creole situations. 


\subsection{Diglossia and the creole continuum}

Creole-speaking communities are often characterized by multilingualism and an asymmetric distribution of functions between languages. The concepts of diglossia and the creole continuum have been used in the study of social functions and variation in creole settings, and are thus essential in the collection and analysis of creole data.

Diglossia refers to situations in which a speech community has two different codes that each have a functional and situational specialization (Wardhaugh 2006, 89). The codes or varieties are clearly separated, and there is little overlap between them and their functions. The variety with a superior status and prestige is labelled a "high" variety $(\mathrm{H})$ and the other a "low" variety (L). The $\mathrm{H}$ variety is often codified, has a literary tradition, is used in school, and functions as a means of social advancement. Creoles are generally $\mathrm{L}$ varieties, meaning that they are vernaculars without any official or public functions. An example of creole diglossia is the situation in St Lucia, where English is the official language, and the majority of the population speaks a French creole. The French creole functions as the L variety and English as the $\mathrm{H}$ variety. The $\mathrm{H}$ variety can also be the lexifier of the creole, as is the case for example in Guadeloupe, where Guadeloupean Creole functions as the L variety and French as the H variety (Hazaël-Massieux 1978).

The creole continuum refers to situations in which a creole language consists of a spectrum of varieties ranging from those most to least similar to the lexifier. The continuum is thus formed by gradations of variation that presuppose a social continuum between the different lects. The lect least similar to the lexifier language is called the basilect, and the one most similar to it is called the acrolect. Between these ends of the continuum, the various intermediate stages are called mesolects (Velupillai 2014, 212). It is often assumed in this model that the basilect represents the "original" creole, while other lects are the result of more recent developments and show a closer resemblance to the lexifier language. However, this should not be taken for granted, but should rather be based on diachronic evidence. A related concept is decreolization, a process in which the creole becomes more and more similar to the lexifier by the transfer of linguistic traits from the lexifier to the creole. However, in many French-lexifier creoles, there is little evidence that the decreolization continuum determines the variation in these languages even if they are in intensive contact with varieties of French (Valdman/Villeneuve/Siegel 2015, 3). Inverse developments could also have been possible in their formation, such that French became more creole-like with each generation of non-native learners (Chaudenson 2001; Bartens 2013, 76).

Diglossia and variation can affect creole situations in various ways. Here we will look at examples from Cape Verde, the Indo-Portuguese communities, and Haiti. In the rural regions of the island of Santiago in Cape Verde, the speakers are under pressure from three different linguistic norms: the local oral village variety of Santiago 
Creole; the urban oral variety of Santiago Creole, which basically corresponds to the dialect of the capital Praia located in the south of the island; and European Portuguese, the official language of the Republic of Cape Verde, both in its written and spoken forms (Quint 2014). The local variety is spoken in the villages and when talking to people from the neighbouring villages. The urban variety of the creole or an approximation of it is used when communicating with outsiders or in settings outside the realm of the local village. The use of this variety in the media, such as on radio and television, also reinforces its social function. Portuguese is the written norm used by the majority of the population, and it is employed exclusively by the administration, press, and media (especially for the news). In this situation, Portuguese can be described as the $\mathrm{H}$ variety, while the local oral variety of Santiago Creole functions as the L variety.

Quint $(2014,86)$ stresses the importance of being conscious of these three norms when collecting data on the local varieties, because the methods of data collection influence the variety spoken by the Cape Verdeans. For example, when eliciting local oral dialectal forms, Quint and his creole-speaking collaborator could not use the urban creole forms in their questions, because it caused the speakers to accommodate towards the urban variety. To elicit more reliable data, they had to resort to indirect questions. Interestingly, comments about other varieties occasionally provided them with insights into the metalinguistic norms in the community and into the prestige relations between the varieties. For example, in a rural community in the northern part of the island, one of the informants gave the local form txóti [ţti] for 'sparrow' and added that na purtugés é [jote] ('in Portuguese it is [jote]'). Actually, this word does not exist in Portuguese. The invented form is a creation that reflects the prestige that both the urban variety and Portuguese have for the speaker: in the urban variety the form is txóta with a final mid-vowel, and in contrast to the local form, there exists no affricate in Portuguese, which motivated the use of [f] (Quint 2014, 88).

In the multilingual community of Diu in India, where besides the historical lexifier Portuguese, Gujarati, Hindi, and English exert prestige over the creole, there exists a common view of a continuum that ranges from the Indo-Portuguese creole to European Portuguese. This continuum also includes other varieties of Indo-Portuguese, and in comparison to the neighbouring creole spoken in Daman, the speakers perceive the creole spoken in Diu to be closer to Portuguese (Cardoso 2007, 175).

In a similar vein, Daman Indo-Portuguese exhibits clear variation between the acrolectal and basilectal varieties where Portuguese is used as a reference point. Differences can be observed in the pronominal system and verbal paradigms, including features such as the presence/absence of the imperfect forms of various verbs and present third singular forms, as well as the formal/familiar distinction in second person pronouns and certain other forms in the pronominal paradigm (Clements 2014, 126-128).

Yet a third Indo-Portuguese creole, that of Korlai, has features that can be classified as more archaic (e.g. a familiar second person pronoun derived from Ptg. 
vós, innovative irregular verb forms, or forms created by analogy) or as having more Indic influence (e.g. postpositions) than Diu and Daman Indo-Portuguese (Clements 2009; 2014). Comparing these three varieties, Diu and Daman are classified as more "acrolectal", due to the more recent presence and influence of Portuguese, while the variety in rural Korlai is more "basilectal" due to a break from the Portuguese influence from 1740 onwards (Clements 2009; 2014; Cardoso 2014).

Although the creole continuum and the notions of "basilect" and "acrolect" are useful concepts in trying to make sense of the variation in a creole community, from both the linguists' and the speakers' points of view, they cannot be directly applied to all cases. For example, discussing the complications in the description of sociolinguistic variation in Haitian Creole, Valdman/Villeneuve/Siegel (2015) conclude that the creole continuum is not applicable to their case. In Haiti, two opposed varieties of the creole can be identified. Kreyòl swa is the more prestigious variety, spoken by the better-off and socially prominent minority, who are also fluent in French. Kreyòl rèk or kreyòl pèp la 'the creole of the people', the variety of the rural, illiterate, monolingual masses, is at the other end of the sociolinguistic continuum. However, some characteristic grammatical features of kreyòl swa also appear in the speech of monolingual speakers, as for example in Isit miyò ke Pòtoprens 'Here it's better than in Port-auPrince' (instead of Isit pi bon pase Pòtoprens). In addition, as the boundary between French and creole lexicon is permeable, even monolingual, rural speakers can have recourse to items from the French lexicon (Valdman/Villeneuve/Siegel 2015, 7). Baptista (2015) reaches similar conclusions about the suitability of a continuum model for the Cape Verdean varieties spoken in Santiago and São Vicente.

Regarding the methodology used in the study of creoles, this social and functional variation means that it is essential to find out which languages the community members speak, and their degrees of competence in different varieties. The researcher should aim to find out where the speaker acquired the languages (e.g. at home, at school, or in the community), and what the functional divide between them is. It can also be helpful to inquire if the languages are a first or a second language.

\subsection{Ideologies and low prestige}

Creoles have been marginal languages throughout their histories due to their relatively recent formation and their lack of autonomy. They are marginalized in political and economic terms, and often spoken in geopolitically remote areas, such as small islands and tropical coastlines (Garrett 2006, 178).

The popular perception that creoles lack history is rooted in the ideologies and folk beliefs about creole speakers' language(s) and the ethnohistories of their communities (Garrett 2006, 179). Due to colonial exploitation and slavery, creole-speaking communities often have their origins in transplanted communities. In Garrett's view, the ethnic identities of the speakers of creole languages may therefore be less 
"focused" or more "diffuse", using the terms of LePage/Tabouret-Keller (1985), and more open to negotiation and contestation than those of the indigenous group(s) from the area. In addition to these factors, the socio-political ideologies dominant in different territories can neglect the reality of the creole communities, as shown for example by the French's alignment with the ideology of the French nation-state in French Guiana (Migge/Léglise 2012, 28).

The lack of autonomy can be seen in that creoles have often been considered "broken" and "corrupted" versions of their lexifiers. Although it is widely recognized that creoles are their own distinct languages, many creole speakers think they speak a form of the lexifier language, which has higher prestige (cf. e.g. Lipski 2010; Lesho/ Sippola 2014, 21-23). This lack of autonomy manifests itself in other ways, as shown by the tendency of some scholars to refer to all of the world's French-lexified creoles in the singular as le créole (Garrett 2006, 183) or to the different Chabacano varieties as Philippine Creole Spanish, although the speaker communities have separate formation histories.

Language attitudes and ideologies have a significant effect on how fieldwork is carried out and what type of data is obtained in creole settings. This is the case especially in settings where there is continued contact with the lexifier, such as in the context of many Portuguese creoles in Africa, Haitian in Haiti, and Daman and Diu Indo-Portuguese creoles. Generally, due to practical reasons, the researcher is working with people who are fluent in both the standard language and the creole, and they might only get data from the standard as a default response. This is especially true if the researcher is a native speaker of the lexifier. In formal contexts such as interviews or data elicitation sessions it is normal to speak the standard, which can make it difficult to access creole data (see also Bowern 2010).

In Diu, overt prestige is exclusively attributed to Portuguese, which leads to variation in the creole data because it facilitates the borrowing of lexifier material and (hyper)correction (Cardoso 2007, 2009). Reasons for using the prestige code range from the social profile of the interlocutor (e.g., when talking to a Portuguese-speaking outsider) to the desire to demonstrate one's social standing. The social asymmetries implied by the contrast between the creole and the lexifier seem to cause linguistic insecurity: Diu Indo-Portuguese speakers may speak very cautiously or ashamedly, switch to another language, e.g. English, or even refuse to speak at all when interacting with a person associated with Standard Portuguese (Cardoso 2007, 175). The low prestige of Diu Indo-Portuguese is also reflected in how it is named. To distinguish it from Portuguese, the native speakers themselves use a variety of expressions, such as the neutral purtəgez do diw 'Portuguese of Diu', but also lig tort 'twisted language', purtagez kebrad 'broken Portuguese', and similar names (Cardoso 2009, 7). This type of naming is common in other creole contexts as well.

Ideologies can also be connected to the perceived ethnic backgrounds of the creole communities. Quint $(2014,89)$ describes how perceptions of ethnicity and race are reflected in the use of Africanisms in Cape Verdean communities. In Santiago, one 
young speaker judged that the Africanism djanbu "feel compassion for someone" (Quint 2008, 102) could not be used on her island, because the population there had a Portuguese origin. However, Quint's survey showed that djanbu is known and commonly used among elderly speakers of the island. In this case, the prestige of the different varieties and the socio-historical characteristics associated with them and their speakers affected the data collection.

\subsection{Language endangerment}

Several small Romance creoles face language endangerment. For example, in the Lesser Antilles, French-lexified creoles are endangered on those islands where French has been displaced by English, such as Trinidad and Grenada, and to a lesser extent, St Lucia (Holbrook/Ferreira 2002; Garrett 2000; 2005; Mitchell 2010) and Dominica (Garrett 2006). This holds also for many situations in Asia, such as the Indo-Portuguese creoles and Papiá Kristang, which are spoken in multilingual communities without a strong lexifier presence. Fortunately, more encouraging experiences have also been observed. For example, in Palenque, Colombia, the revitalization of Palenquero appears to be producing noticeable results. The knowledge of the creole has grown considerably, and its use has become a manifestation of ethnic pride (Lipski 2012, 26).

Language obsolescence presents a major problem for data collection in many endangered creole communities, such as the Malabar Coast in India (Cardoso p.c.), Cavite in the Philippines (Lesho 2013; Lesho/Sippola 2013), and some French creole communities in the Caribbean (Holbrook/Ferreira 2002). In these groups, many speakers no longer use the creole frequently and consequently lack fluency in the language. A break in intergenerational language transmission is common, meaning that the community is undergoing language shift, and the remaining fluent speakers are of the grandparental generation or older. A good example is Lesho's (2013) sociophonetic study of Cavite Chabacano, where the language endangerment situation had an effect on the participant design. Chabacano is severely endangered in Cavite City (Lesho/ Sippola 2013), and equal numbers of participants were difficult to recruit in each demographic category. Only eight of the 47 participants were below age 50 at the time of recording (Lesho 2013, 105). Language obsolescence and a strong decrease in the size of the speech community also reduce the degree of internal variation found in the creole language data. This is the case, for example, in the Indo-Portuguese communities of Cannanore and Cochin (Cardoso 2014, 109). 


\section{Data collection and analysis in creole settings}

Creole societies are typically associated with the extensive linguistic variability that reflects the multiple, often conflicting, social and linguistic requirements imposed on creole speakers throughout their turbulent history. Creole societies that inherited this history still exhibit language continua that require accurate empirical methods of analysis if the complete span of the continuum is to be investigated (Escure 2008).

\subsection{Ethical aspects in working with creole languages}

Sociolinguistics has long recognized the critical goal of conducting ethical research in the field and in speech communities (Trecher 2013). In creole studies, this aim has also been recognized (e.g. Rickford 1997), although it has not always been explicitly formulated. The power relations present in the field setting - either between the creole and the lexifier or other official languages, or between the researcher and the participants - should be carefully considered before embarking on a research project, as they may have an effect on the data and analysis as well as the status and situation of the community. Rickford $(1997,186)$ believes that researchers should get involved in the "application, advocacy, and empowerment" of marginalized contact varieties, because as researchers we owe it to the people whose data we use in the formulation of our theories and descriptions.

The question of what counts as "authentic" creole data is a good example of the challenges associated with the role of the researcher in creole situations (Lacoste/Mair 2012; Lesho/Sippola 2014, 5). Sometimes researchers discard data, because they think they are not "authentic" or basilectal enough, but actually provide a study of the creole using their own metalinguistic systems through their own ideological lens (Mühlhäusler 1983; Gal/Irvine 1995).

Answers to ethical questions are not clear-cut and vary from one setting to another, but researchers should reflect on ethics, sociopolitical relationships, and power dynamics at every stage of their research.

\subsection{The creole community in context}

Many Romance creoles are situated in multilingual and multiethnic areas, and in such situations it is essential to have an understanding of the community in its social, historical, and cultural context (see also Bowern 2010, 340; Meyerhoff et al. 2012, 129). A case in point is French Guiana, a multilingual space where several Amerindian languages, English-based creoles, French-based creoles, European languages, and varieties of Hmong and Chinese are used (Migge/Léglise 2012, 43-45). French Guianese Creole (Guyanais) used to be the main lingua franca, but other lingua francas are 
also used in different parts of the country, e.g. Guyanais and Brazilian Portuguese in the East, a set of varieties of Surinamese creoles in the West, and French in both parts. Moreover, speakers regularly alternate between languages and varieties in their repertoires. This alternation can occur within the same context and the same situation, and it includes borrowing, code-switching, transfer and imposition, and convergence phenomena (Migge/Léglise 2012, 46). In such situations, it is difficult to isolate "a creole" from other multilingual practices of the community as reflecting the social behaviour of the speakers. Ethnographic methods and participant observation can give the researcher a better knowledge of the community and the language contact situation in general (Bowern 2010).

\subsection{Outsiders' access to creole data}

Due to their historical legacy, speakers of creole languages often have a vast repertoire of styles, varieties or lects, and sometimes languages, but the extent of an individual's repertoire is not easily observable by casual outsiders because of the stigma that is still attached to creoles, especially in their basilectal forms. The creole is often reserved for spontaneous in-group interaction, and in talking with outsiders speakers naturally switch to some acrolectal variety that they know will be understood (Escure 2008, cf. 4.1). Researchers are rarely members of the communities they study, which can create challenges for data collection. Being a foreigner, of a different ethnicity, or a non-native speaker of the language will influence the relationship between the speakers and the linguist more generally (Briggs 1986; Meyerhoff et al. 2012, 129). In addition, the role of the researcher as a highly educated, Western or Northern outsider can be problematic in communities whose language has low prestige (cf. 3.2).

First, the ethnic and physical characteristics of a researcher can hinder the collection of "authentic" data, as some speakers suppress their creole when faced with someone who is considered an outsider to the community. In a study of variation in Haitian Creole (Valdman/Villeneuve/Siegel 2015, 15), far fewer tokens of any possible variables appeared in interviews that were conducted by a white Canadian. A number of speakers seemed less talkative in a one-to-one setting with this interviewer, probably because they interpreted him to be an outsider. This happened despite the fact that the interviewer in question had near-native proficiency in the creole and his wife is a native of the city where the interviews were conducted. When the interviewer was a Haitian from Port-au-Prince, it was easier to conduct the interviews. In this particular case, the solution was to exclude the data from their analysis, due to the imbalance in the material.

Second, as mentioned in 3.2, the normative pressure of the lexifier language is often problematic in these settings. Quint $(2014,88)$ provides a concrete example of the influence of the prestige variety on the creole data collected by interviewers who are seen as outsiders to the community. In the southern varieties of Cape Verdean (in 
Brava, Fogo, Maio, and Santiago), the affricate [t'] is used in the forms [ke'tfor, ke'tfol, ke'tfoj, ka'tfor, 'katfo] 'dog', which is retained from classical Portuguese cachorro [ke 'tforru]. However, when interviewed by the French researcher and his Cape Verdean colleague, some informants on the island of Maio accommodated towards the prestige variety by providing a form with the modern Portuguese sound [ $[$ ] instead of the affricate. Even the presence of a Cape Verdean interviewer, who came from a different part of the archipelago, did not prevent the influence of the prestige variety. Peers participating in the working session corrected the answers or other forms appeared later on, which lent support to the researchers' initial suspicions about the data.

Similarly, in multilingual French Guiana, where French functions as a lingua franca and is widely used in daily interactions, the presence of French-speaking researchers accentuates the use of French even further and hinders access to naturalistic data from multilingual interactions. To overcome this potential problem and elicit more reliable data from a variety of contexts and locations, such as interactions within the family or on school playgrounds, local community members record their own interactions without the presence of the researcher (Migge/Léglise 2012, 40; Léglise p.c.).

\subsection{Participant observation and interviews}

Reliable results from creole settings require a wide range of methods and often a commitment to fieldwork over a long period of time (Lesho/Sippola 2013). Participant observation is needed, as other methods, such as surveys and interviews, might produce inaccurate responses (Escure 2008). For example, during data collection in a Chabacano-speaking town, some speakers first denied knowing the creole, but later proved to be fluent speakers after the researcher had gained more trust by spending more time living in the community and overheard them speaking the language several times. Also, in an initial language use questionnaire, a speaker claimed to have lived all his life in the same creole-speaking town, but later on during an interview he told lively stories about his teenage years in Manila (Lesho/Sippola 2013, 23).

Similarly, Valdman/Villeneuve/Siegel $(2015,33)$ describe a situation where the interviewers attempted to elicit the use of a possessive construction with parts of the body, in order to determine the level of awareness of the variable constructions. In many cases, speakers produced the standard Haitian Creole variant in the elicited questions, even though the corresponding regional Capois variant occurred commonly in the rest of the guided conversation. For example, one of the participants, a rural adult male, who in the rest of the interview used the Capois variant $X$ an mwen or Xanm 'my X' in a great majority of the cases, used the standard Haitian Creole form $X$ mwen (e.g. figi mwen 'my face', je mwen 'my eye') in the elicited answers.

Lesho/Sippola $(2013,22)$ see long-term participant observation as an especially useful tool for evaluating language vitality and for providing perspective on changes 
in the sociolinguistic situation over time. This methodology can also be applied where there are other goals. By becoming more integrated into the community over a longer period of time, the researcher is not limited to the language data or sociolinguistic information provided by only a few select language activists, but has access to more unguarded language-use situations in which people are not necessarily trying to promote one view of their language over another.

As is well known from sociolinguistic research in general, in an interview situation, the presence of the researcher, the recording of the speech, and the nature of the task at hand can hinder the collection of creole data in natural discourse contexts. At the structural level, early claims of lexifier-like or decreolized varieties may actually have reflected formal interviews that excluded discourse contexts (Escure 2008). Several methods can be used to mitigate the effects of these problems (for an overview, cf. Meyerhoff et al. 2012, 132). Here we will focus on task types and topics.

From the anthropological perspective, the interactional set-up of an interview requires a culturally marked format of communication, which means face-to-face interaction between the interviewer and interviewee and direct questions and answers to them. This format is not necessarily equally familiar to all sections of the population, as was the case in French Guiana (Migge/Léglise 2012, 14). In situations where an interview setting was not productive, data were collected during informal discussions while sharing people's daily activities.

In an interview situation, group sessions with many participants can make the situation less formal. Similarly, using community members as (co-)interviewers can help to lessen the effects of the presence of the interviewer. This method has been employed in several studies; for example, Quint $(2014,89)$ works in collaboration with a Cape Verdean interviewer, Sippola (2011) works with local assistants in Ternate, and Valdman/Villeneuve/Siegel (2015, 13-16) had native speakers of the regional variety as field interviewers. The selection of community members for data collection should be done keeping in mind the lectal variation and social prestige associated with it, as teachers, for example, can be more likely to produce more acrolectal forms and exert prestige and/or control over the linguistic production of other members in the community. A further difficulty of using group interviews or speakers as interviewers without the presence of the researcher is that the researcher has no control over the interview or its flow. The data obtained with large groups often includes overlapping speech and is harder to transcribe and process, especially if the transcriber was not part of the recorded interaction.

The questions asked in a sociolinguistic interview have an important effect on the style and register of the interaction, and sometimes even the language. Some questions are likely to be suitable for most people in any community, such as family, childhood, dreams, etc., while others might be highly inappropriate (Meyerhoff et al. 2012, 134). As the settings of creole communities differ greatly, there is no clear answer as to what to ask in each community, but some possible pitfalls should be kept in mind. On the one hand, if the creole language is used mainly in informal settings and 
another language dominates in the public and official domains, the topics should be directed accordingly, as these very probably trigger the use of different codes and thus synchronic variation in the creole data. In Valdman/Villeneuve/Siegel $(2015,16)$, the topics with adult participants included means of livelihood, differences in life and culture between the past and the present, community events (festivals, religious ceremonies), and pastimes. With adolescents, the conversations were about favourite school subjects and games. The speakers also gave summaries of the telenovelas they watched on television. On the other hand, text types such as traditional stories are more likely to be memorized by rote, and can thus present more archaic forms, as shown by Clements (1990) for Korlai Indo-Portuguese.

\subsection{Surveying creoles}

Sociolinguistic surveys have the advantage of gathering a large number of participants with a relatively quick response and collection time; however, they are limited in the type of data they can collect. For example, Fattier (1998) provides data on more than two thousand linguistic variables involving phonological, grammatical, and lexical features in Haitian Creole. Connecting this information to sociolinguistic variables other than geographical region might be a challenge, although generally background information about the consultants is given.

The French creole atlases are based on dialectal surveys, collected orally with teams of local, often creole-speaking students and/or researchers and transcribed by the same. For example, in the case of the dialectal work in the Lesser Antilles, the data were collected from one main consultant in each location. However, the authors mention that family members and neighbours often participated and supported the consultant's answers (Le Dû/Brun-Trigaud 2011). The questionnaires contained words and sentences organized into themes (e.g. weather, nature, social life, etc.). In addition to the description of the data collection, the atlas also provides an introduction to the sociocultural background and education level of the consultants, which allows the results to be contrasted with individual traits.

Surveys about language use, attitudes, and perceptions can be conducted in different ways. Migge/Léglise (2012) carried out ten-minute interviews with 2,000 schoolchildren in French Guiana, Atchia-Emmerich $(2005,67)$ used both interview and written survey data from different age, ethnic, and social groups, and Lesho/ Sippola (2014) conducted an online survey about Chabacano speakers' folk perceptions of each other's varieties. However, an accurate assessment of speaker preference or competence in language production and comprehension cannot be based solely on subjective self-reported use. Surveys that rely on speakers' beliefs and self-reported language use are valuable in the sense that they provide insights into local attitudes toward language use, but do not produce a comprehensive picture of the creole situation and should be complemented with other types of data (Escure 2008). What 
is common for all the studies mentioned here is that the survey data were contrasted and controlled against data obtained using other methods.

\section{Chabacano folk perceptions}

This section presents a case study of perceptual dialectology in the Chabacano-speaking communities in the Philippines. It shows how combining a variety of approaches in data collection can help to minimize researcher bias in data analysis and to study creole sociolinguistics in a more comprehensive way.

Chabacano is the common name used for several creole varieties that have Spanish as the lexifier and Philippine languages as the adstrates. Lesho/Sippola (2014) used folk linguistic methods to study the variation among the Chabacanospeaking communities and attitudes towards different languages spoken in them. They focused on the linguistic features that Chabacano-speakers identify as characteristic of the varieties, aspects of how this perceived variation is evaluated socially, and the relationships of each variety to Spanish, the Philippine languages, and English. They also evaluated the differences between linguist and speaker perceptions. The speakers' folk perceptions do not always align with their documented production. However, the matches and mismatches between the two help to gain new insights into the ideologies that speakers have about different varieties spoken in their communities. Taking folk perceptions into account can help researchers reach a better understanding of what is considered "authentic" creole and the complex dynamics of creole-speaking communities in general (Lesho/Sippola 2014, 3-5).

The study was based on a variety of qualitative sociolinguistic methods, including qualitative analysis of sociolinguistic interviews, interviews from a perceptual map task, and an online survey. The material collected using these methods was combined and cross analysed.

\subsection{Methods of perceptual dialectology}

Lesho/Sippola (2014) conducted sociolinguistic interviews in Cavite City and Ternate over a period of ten years, and with occasional diaspora speakers in the USA. Participants had various backgrounds, although teachers, language activists, and other people interested in the histories of the communities formed a majority. A total of 108 native or near-native speakers were interviewed from traditionally Chabacanospeaking neighbourhoods. The age of the people interviewed ranged between 11 and 87 years, but different age groups were unequally represented due to the language endangerment situation, especially in Cavite City. The topics focused on language use and attitudes, such as the participants' best and preferred language in different domains, the languages they used/understood when listening/reading/writing, the 
linguistic history of their family, the future of the Chabacano language, and a variety of general topics. The majority of the interviews were conducted in Chabacano, with occasional switching to English and Tagalog, as codeswitching is common in these communities in everyday speech. Typical interviews lasted around 30-45 minutes. In addition, a map labelling task was conducted in Cavite City by Lesho with 27 participants, who were instructed to label where on the map people still speak Chabacano and to comment on how people speak in different areas (Lesho 2013, 122-123). The interviews and map labelling tasks were audio- or video-recorded, which proved useful for collecting examples of how participants imitate the pronunciation or intonation of other varieties. The results of the interviews were generally checked against participant observation. In addition to the interview and task sessions, systematic information was collected on the personal backgrounds, language use, and preferred languages in these two communities (cf. Lesho/Sippola 2013).

Data from Zamboanga, the largest Chabacano-speaking community, came from an online survey with similar content to the interview data, but they were not contrasted with data from participant observation. Due to the variable types of data employed in the study, the treatment and the presentation of the analysed material aimed at transparency. All the examples and further information about the perceptions reported in the study indicate the age, sex, community, and language history of the participants, as well as the material types that were used, in order to contextualize the individual data points.

\subsection{Chabacano speaker perceptions as a tool to explore creole dynamics}

Both the interviews and the survey results in Lesho/Sippola (2014) showed that the Chabacano speakers in each community consider the three varieties to be separate but mutually intelligible languages, differing mainly in terms of the lexicon and phonology. These linguistic differences were attributed to each variety's perceived closeness to Spanish or the Philippine languages, with regard to geographical location, register, social class, and age. Language shift to Philippine languages was perceived as a threat, even in the most vital community of Zamboanga. The prestige of English seemed to protect it from negative perceptions. For historical reasons, Spanish was perceived as a prestige variety, with several positive linguistic and ethnic connotations. However, "pure" or "legitimate" Chabacano was considered to be distinct from Spanish, and it was tied to the local identities and contexts.

When comparing the data gathered from the interviews, the map task, and the online survey, the outcomes were very similar. In all data types phonological and lexical variation were highlighted, with the latter explained by adstrate influence. Much less attention was drawn to grammatical elements, such as pronouns and prepositions. Some of the differences regarding lexical or phonological variation 
could probably be explained by more detailed studies about dialectal or stylistic variation in Chabacano. In general, compared to the other data types, the survey data seemed to present more examples of variation that matched linguists' observations, which can probably be explained by the respondents' interest in language issues and in taking the survey.

Lesho/Sippola (2014) point out that creolists have often focused on theoretical discussions or historical problems, largely motivated by the explanation of the creolization process and centred on morphosyntactic phenomena, rather than on the types phonological or lexical features that are perceptually salient to the speakers. The perspectives of native speakers have often been lost as creolists impose their own metalinguistic systems onto their analyses. Long-term fieldwork including participant observation, together with elicitation methods from perceptual dialectology, is another way to minimize researcher bias and to explore the social dynamics of creole situations in a holistic, ethical way.

\section{Conclusions}

This chapter has discussed some methodological challenges in the collection and analysis of creole data. As in the study of any other type of language, creoles need to be studied with carefully selected methods for each particular study. The sociohistories of many creole communities, the prestige asymmetries related to them, and their multilingual or -lectal nature create special requirements regarding the methods in the study of variation and change in creole languages.

The collection and analysis of creole data has to be based on ethical principles and informed by participant observation or participatory research. The results obtained by different methods, such as questionnaires, interviews, and participant observation, can be contradictory, but these contradictions can also be seen as providing interesting insights into speakers' metalinguistic systems and the general situation of creole-speaking communities. By combining and contrasting several methods and analysing the ambiguities in context, the researcher can gain access to relevant information on the language attitudes and ideologies that affect socially conditioned developments and variation in creoles.

Acknowledgements: The author wishes to thank Angela Bartens, Hugo Cardoso, Anthony Grant, Philipp Krämer, Bettina Migge, Edward Mitchell, Isabelle Léglise, Marivic Lesho, and Nicolas Quint for their help and making many references available. 


\section{Bibliography}

Atchia-Emmerich, Bilkiss (2005), La Situation linguistique de l'île Maurice: Les Développements récents à la lumière d'une enquête empirique, Erlangen, Universität Erlangen.

Baker, Philip/Corne, Chris (1982), Isle de France Creole: Affinities and Origins, Ann Arbor, Karoma.

Bakker, Peter, et al. (2011), Creoles are Typologically Distinct from Non-Creoles, Journal of Pidgin and Creole Languages 26(1), 5-42.

Baptista, Marlyse (2015), Continuum and Variation in Creoles. Out of Many Voices, One Language, Journal of Pidgin and Creole Languages 30(2), 225-264.

Bartens, Angela (2013), Creole Languages, in: Yaron Matras/Peter Bakker (edd.), Contact Languages. A Comprehensive Guide, Berlin/Boston, De Gruyter, 65-158.

Bavoux, Claudine/Prudent, Lambert-Félix/Wharton, Sylvie (edd.) (2008), Normes endogènes et plurilinguisme. Aires francophones, aires créoles, Lyon, ENS Éditions.

Bollée, Annegret (1993), Language Policy in the Seychelles and its Consequences, International Journal of the Sociology of Language 102, 85-100.

Bollée, Annegret/Nembach, Pamela (2006), Diatopic Variation in Haitian Creole, in: J. Clancy Clements et al. (edd.), History, Society, and Variation. In Honour of Albert Valdman, Amsterdam/Philadelphia, Benjamins, 225-232.

Bowern, Claire (2010), Fieldwork in Contact Situations, in: Raymond Hickey (ed.), The Handbook of Language Contact, Oxford, Wiley-Blackwell, 340-357.

Briggs, Charles (1986), Learning How to Ask: A Sociolinguistic Appraisal of the Role of the Interview in Social Science Research, Cambridge, Cambridge University Press.

Carayol, Michel/Chaudenson, Robert (1978), Diglossie et continuum linguistique à la Réunion, in: Nicole Gueunier/Emile Genouvrier/Abdelhamid Khomsi (edd.), Les Français devant la norme, Paris, Champion, 175-190.

Carayol, Michel/Chaudenson, Robert/Barat, Christian (1984-1995), Atlas linguistique et ethnographique de la Réunion, 3 vol., Paris, Éditions du CNRS.

Cardoso, Hugo (2007), Linguistic Traces of Colonial Structure, in: Eric Anchimbe (ed.), Linguistic Identity in Postcolonial Multilingual Spaces, Newcastle upon Tyne, Cambridge Scholars Publishing, 164-181.

Cardoso, Hugo (2009), The Indo-Portuguese Language of Diu, Utrecht, LOT.

Cardoso, Hugo (2010), African Slave Population of Portuguese India: Demographics and Impact on Indo-Portuguese, Journal of Pidgin and Creole Languages 25(1), 95-119.

Cardoso, Hugo (2014), Factoring Sociolinguistic Variation into the History of Indo-Portuguese, Revista de crioulos de base lexical portuguesa e espanhola 5, 87-114.

Chaudenson, Robert (1979), À propos de la genèse du créole mauricien: Le Peuplement de l'île de France de 1721 à 1735, Études créoles 2, 43-57.

Chaudenson, Robert (2001), Creolization of Language and Culture, London/New York, Routledge.

Chaudenson, Robert/Carayol, Michel/Barat, Christian (1992), Atlas linguistique et ethnographique de l'île Rodrigues, Paris, Agence de Coopération Culturelle et Technique.

Clements, Clancy (1990), Deletion as an Indicator of SVO $\rightarrow$ SOV Shift, Language Variation and Change 2(2), 103-133.

Clements, Clancy (2009), Accounting for Some Similarities and Differences among the Indo-Portuguese Creoles, Journal of Portuguese Linguistics 8(2), 23-47.

Clements, Clancy (2014), Lectal Differences in Daman Indo-Portuguese, Revista de crioulos de base lexical portuguesa e espanhola 5, 115-156.

DeGraff, Michel (2005), Linguists' Most Dangerous Myth: The Fallacy of Creole Exceptionalism, Language in Society 34, 533-591. 
Dupré, Florence (2013), TXT MSG'ing among French Reunion 18-to-25-Year-Olds: A Pilot Study of Mobile-Mediated Communication in a Diglossic Context, Journal of Pidgin and Creole Languages 28(1), 137-153.

Escure, Geneviève (2008), Pidgins/Creoles and Discourse, in: Silvia Kouwenberg/John V. Singler (edd.), The Handbook of Pidgin and Creole Studies, Malden, MA, Wiley-Blackwell, 567-592.

Fattier, Dominique (1998), Contribution à l'étude de la genèse d'un créole: L'Atlas linguistique d'Haïti, cartes et commentaires, 6 vol., Villeneuve d'Ascq, Presses Universitaires du Septentrion.

Fernández, Mauro/Sippola, Eeva (2017), A New Window into the History of Chabacano, Journal of Pidgin and Creole Languages 32(2), 304-338.

Ferreira, Jo Anne (2009), The History and Future of Patuá in Paria. Report on Initial Language Revitalization Efforts for French Creole in Venezuela, Journal of Pidgin and Creole Languages 24 (1), 139-158.

Fleischmann, Christina Tamaa (2008), Pour mwan mon lalang maternel i al avek mwan partou. $A$ Sociolinguistic Study on Attitudes towards Seychellois Creole, Bern, Lang.

Gal, Susan/Irvine, Judith T. (1995), The Boundaries of Languages and Disciplines: How Ideologies Construct Difference, Social Research 62, 967-1001.

Garrett, Paul (2000), “High” Kwéyòl: The Emergence of a Formal Creole Register in St. Lucia, in: John H. McWhorter (ed.), Language Change and Language Contact in Pidgins and Creoles, Amsterdam/ Philadelphia, Benjamins, 63-101.

Garrett, Paul (2005), What a Language is Good for: Language Socialization, Language Shift, and the Persistence of Code-Specific Genres in St. Lucia, Language in Society 34(3), 327-361.

Garrett, Paul (2006), Contact Languages as Endangered Languages: What is there to Lose?, Journal of Pidgin and Creole Languages 21(1), 175-190.

Graham, Steve (2001), A Look at the Acts of Identity Theory through a Social Network Analysis of Portuguese-Based Creoles in West Africa, Journal of Pidgin and Creole Languages 16, 1-51.

Hagemeijer, Tjerk/Zamora, Armando (2016), Fa d'Ambô: Past and Present, International Journal of the Sociology of Language 239, 193-209.

Hazaël-Massieux, Guy (1978), Approche socio-linguistique de la situation de diglossie français-créole en Guadeloupe, Langue française 37, 106-118.

Hazaël-Massieux, Marie-Christine (1993), Écrire en créole. Oralité et écriture aux Antilles, Paris, L'Harmattan.

Hazaël-Massieux, Marie-Christine (2002), La Codification des créoles, avec un regard particulier sur le créole antillais, in: Dominique Caubet/Salem Chaker/Jean Sibille (edd.), Codification des langues de France, Paris, L'Harmattan, 207-218.

Hebblethwaite, Benjamin (2009), Scrabble as a Tool for Haitian Creole Literacy: Sociolinguistic and Orthographic Foundations, Journal of Pidgin and Creole Languages 24(2), 275-305.

Holbrook, David J./Ferreira, Jo-Anne S. (2002), Are they Dying? The Case of Some French Lexifier Creoles, La torre - Revista de la universidad de Puerto Rico (El Caribe anglófono) 7, 367-398.

Holm, John A. (1988-1989), Pidgins and Creoles, Cambridge, Cambridge University Press.

Kremnitz, Georg (1983), Français et créole: ce qu'en pensent les enseignants. Le Conflit linguistique à la Martinique, Hamburg, Buske.

Lacoste, Veronique/Mair, Christian (2012), Authenticity in Creole-Speaking Contexts: An Introduction, Zeitschrift für Anglistik und Amerikanistik 60(3), 211-215.

Le Dû, Jean/Brun-Trigaud, Guylaine (2011), Atlas linguistique des petites Antilles, vol. 1, Paris, Éditions du comité des travaux historiques et scientifiques.

Léglise, Isabelle (2005), Contacts de créoles à Mana (Guyane française): Répertoires, pratiques, attitudes et gestion du plurilinguisme, Études créoles 28(1), 23-57.

LePage, Robert/Tabouret-Keller, Andrée (1985), Acts of Identity: Creole-Based Approaches to Language and Ethnicity, Cambridge, Cambridge University Press. 
Lesho, Marivic (2013), The Phonetics and Phonology of the Cavite Chabacano Vowel System, doctoral thesis, Columbus, $\mathrm{OH}$, The Ohio State University.

Lesho, Marivic/Sippola, Eeva (2013), The Sociolinguistic Situation of the Manila Bay Chabacano-

Speaking Communities, Language Documentation and Conservation 7, 1-30.

Lesho, Marivic/Sippola, Eeva (2014), Folk Perceptions of Variation among the Chabacano Creoles,

Revista de crioulos de base lexical portuguesa e espanhola 5, 1-46.

Lipski, John M. (1986), The Reduction of /s/ in Philippine Creole Spanish and its Implications for Historical Hispanic Dialectology, Diachronica 3, 43-66.

Lipski, John M. (2001), The Place of Chabacano in the Philippine Linguistic Identity, Sociolinguistic Studies 2(2), Shedding Light on the Chabacano Language, 119-163.

Lipski, John M. (2010), Chabacano y español: resolviendo las ambigüedades, Lengua y migración 2(1), 5-41.

Lipski, John M. (2012), The "New" Palenquero: Revitalization and Re-Creolization, in: Richard FileMuriel (ed.), Varieties of Colombian Spanish, Frankfurt/Madrid, Iberoamericana/Vervuert, 21-41.

Ludwig, Ralph (ed.) (1989), Les Créoles français entre l'oral et l'écrit, Script-Oralia 16, Tübingen, Narr.

Ludwig, Ralph/Telchid, Sylviane/Bruneau-Ludwig, Florence (edd.) (2001), Corpus créole. Textes oraux dominicais, guadeloupéens, guyanais, haïtiens, mauriciens et seychellois, Hamburg, Buske.

McWhorter, John H. (2005), Defining Creole, Oxford, Oxford University Press.

Meyerhoff, Miriam, et al. (2012), Sociolinguistic Fieldwork, in: Nick Thieberger (ed.), The Oxford Handbook of Linguistic Fieldwork, Oxford, Oxford University Press, 121-146.

Michaelis, Susanne M., et al. (edd.) (2013), The Survey of Pidgin and Creole Languages, vol. 2: Portuguese-Based, Spanish-Based, and French-Based Languages, Oxford, Oxford University Press.

Migge, Bettina/Léglise, Isabelle (2012), Exploring Language in a Multilingual Context: Variation, Interaction and Ideology in Language Documentation, Cambridge, Cambridge University Press.

Migge, Bettina/Léglise, Isabelle/Bartens, Angela (edd.) (2010), Creoles in Education. An Appraisal of Current Programs and Projects, Amsterdam/Philadelphia, Benjamins.

Mitchell, Edward S. (2010), St. Lucian Kwéyòl in St. Croix: A Study of Language Choice and Attitudes, Newcastle upon Tyne, Cambridge Scholars Publishing.

Morton, Thomas Barry (2005), Sociolinguistic Variation and Language Change in El Palenque de San Basilio (Colombia), doctoral thesis, Philadelphia, University of Pennsylvania.

Mufwene, Salikoko S. (2008), Language Evolution, London, Continuum.

Mühleisen, Susanne (2005), Introduction: Creole Languages in Creole Literatures. Status and Standardization, Journal of Pidgin and Creole Languages 20(1), 1-14.

Mühlhäusler, Peter (1983), Learning to Speak about Speaking in a Pidgin Language, in: Stephen Wurm (ed.), Papers in Pidgin and Creole Linguistics no. 3, Canberra, Australian National University, 93-103.

Nordhoff, Sebastian (2013), The Current State of Sri Lanka Portuguese, Journal of Pidgin and Creole Languages 28(2), 425-434.

Quint, Nicolas (2008), L'Élément africain dans la langue capverdienne/Africanismos na língua caboverdiana, Paris, L'Harmattan.

Quint, Nicolas (2014), Décrire des langues et des variétés de langue peu étudiées. De quelques difficultés rencontrées sur le terrain, in: Gilles Forlot/Fanny Martin (edd.), Regards sociolinguistiques contemporains: Terrains, espaces et complexités de la recherche, Paris, L'Harmattan, 79-96.

Rickford, John Russel (1997), Unequal Partnership: Sociolinguistics and the African American Speech Community, Language in Society 26(2), 161-197. 
Schieffelin, Bambi/Doucet, Rachelle (1994), The “Real” Haitian Creole: Ideology, Metalinguistics and Orthographic Choice, American Ethnologist 21(1), 176-200.

Schnepel, Ellen M. (2004), In Search of a National Identity: Creole and Politics in Guadeloupe, Hamburg, Buske.

Singler, John V. (1995), The Demographics of Creole Genesis in the Caribbean: A Comparison of Martinique and Haiti, in: Jacques Arends (ed.), The Early Stages of Creolization, Amsterdam/ Philadelphia, Benjamins, 203-232.

Sippola, Eeva (2010), Chabacano for Everyone? Chabacano Language Projects in Cavite City in Comparison with Other Chabacano Communities, in: Bettina Migge/Isabelle Léglise/Angela Bartens (edd.), Creoles in Education: An Appraisal of Current Programs and Projects, Amsterdam/Philadelphia, Benjamins, 55-80.

Sippola, Eeva (2011), Una gramática descriptiva del chabacano de Ternate, Helsinki, Unigrafia.

Tobar Delgado, Eduardo (2014), Estudio de lingüística popular en redes sociales online en chabacano zamboangueño: una visión panorámica, Revista de crioulos de base lexical portuguesa e espanhola 5, 47-86.

Tomás, Maria Isabel (2009), The Role of Women in the Cross-Pollination Process in the Asian Portuguese Varieties, Journal of Portuguese Linguistics 8(2), 49-64.

Trecher, Sara (2013), Social Ethics for Sociolinguistics, in: Christine Mallinson/Becky Childs/Gerard Van Herk (edd.), Data Collection in Sociolinguistics. Methods and Applications, New York, Routledge, 33-45.

Valdman, Albert (2005), Vers la standardisation du créole haïtien, Revue française de linguistique appliquée 10, 39-52.

Valdman, Albert/Villeneuve, Anne-José/Siegel, Jason F. (2015), On the Influence of the Standard Norm of Haitian Creole on the Cap Haïtien Dialect. Evidence from Sociolinguistic Variation in the Third Person Singular Pronoun, Journal of Pidgin and Creole Languages 30(1), 1-43.

Velupillai, Viveka (2014), Pidgins, Creoles and Mixed Languages. An Introduction, Amsterdam/Philadelphia, Benjamins.

Wardhaugh, Ronald (2006), An Introduction to Sociolinguistics, Oxford, Blackwell. 